\title{
XIV. Description of a volcanic eruption in the Island of Sumbawa
}

\author{
Mr. G.A. Stewart
}

To cite this article: Mr. G.A. Stewart (1820) XIV. Description of a volcanic eruption in the Island of Sumbawa, Philosophical Magazine Series 1, 56:268, 96-100, DOI: $10.1080 / 14786442008652373$

To link to this article: http://dx.doi.org/10.1080/14786442008652373

册 Published online: 23 Jul 2009.

Submit your article to this journal $\sqsubset \pi$

Џ Article views: 3

Q View related articles $\asymp$ 
permitted him to examine, he bore away to the North and pursued his voyage.

On his arrival at Valparaiso he communicated his discovery to Captain Sherriff of H. M. S. Andromache, who happened to be there. Captain S. immediately felt the importance of the communication, and lost not a moment in making every arrangement for following it up ; he immediately dispatched the William, with officers from the Andromache : and in this stage the last letter from Chili left the expedition, with the most sanguine expectation of success, and ultimate arlvantages resulting from it: and, if we are correctly informed, a fully detailed narrative has been forwarded to Government.

On taking a cursory vicw of the charts of the Southern Atlantic and Pacific Oceans, it will be seen, that though Captain Cook penetrated to a much higher latitude, and consequently drew his conclusion from observing nothing but vast mountains of ice, it will be seen also that his meridian was 45 degrees further to the west of New South Shetland, leaving a vast space unexplored on the parallel of $62^{\circ}$ between that and Sandwich Land, in longitude about $2 S^{\circ}$ west. He again made $67^{\circ}$ or thereabouts, but in longitude $137^{\circ}$ to $147^{\circ}$ west. Perouse ascended no higher than $60^{\circ} 30^{\prime}$; Vancouver about $55^{\circ}$; other navigators passing the Straits of Magellan and Le Maire; and most of them passing as close to Cape Horn as possible, in order, as they thnught, to shorten the passage to the Pacific, are circumstances that reasonably account for the protracted period to which so important a discovery has been delayed.

XIV. Description of a Volcanic Eruption in the Island of Sumbawa. By Mr. G.A. StEWART*.

$I_{N}$ the month of April, IS15, there occurred on the island of Sumbawa a volcanic eruption as tremendous perhaps in its nature, and as destructive in its effects, as any on record.

The mountain from which this took place is called Tanbora. Its summit is calculated to be in latitude $8^{\circ} 20^{\prime} \mathrm{S}$. and in longitude $118^{\circ} \mathrm{E}$. The calculations for this were made from solar lunar observations taken near the mountain by Captain Eatwell, then commanding the Honourable Company's cruizer Benares. Its base is of great extent; but its summit did not to me appear higher than from 5000 to 7000 feet above the sea, which washes the base of the hill for three-fourths of its extent. From ships passing near it, it has been often observed to throw out smoke and

* From the Transactions of the Literary Society of Bombay, rol. ii.

dist: 
dust with some noise. In the month of December, 1814, the Honourable Company's cruizer Ternate passed near it, and we had an opportunity of observing the hill, though at a very considerable distance. It was then emitting smoke in a dense column of inmense circumference. So very great was the diameter of the column of smoke, and so dense was it, that we at first took it for part of the mountain; for at the distance we were off, the mountain and the smoke had nearly the same colour.

From the 5 th to the 11 th of A pril, 1815, the mountain emitted dust and frequent loud sounds every day. The dust caused a haziness of the atmosphere at places many degrees distant from Tanbora; and the noises which were heard equally far off, sounded at Beema (a to yn about sixty miles east of the hill) generally like the firing of the largest cannon close to the ear; at other times the noises were of a rumbling kind.

On the night of the 10th and morning of the 11 th of April the loudness and frequency of the reports increased. 'The showers of greyish black dust which had been falling at Beema increased so much by 7 A.M. on the 11 th, as to produce there it total darkuess. This complete darkness continued until 7 A.M. on the 12th, after which the dust fell in less and less quantity, and at noon it entirely ceased.

Pumice-stone of a brown colour was thrown out in immense quantity at the crater of the mountain. Great fields of it, with scorched trunks and branches of trees, were afterwards found floating in the neighbouring sea; and much of these were thrown up on the shores of Bally Java, Madura, Celebis, \&c. These shoals were troublesome, and even somewhat dangerous, to ships passing near them. The country ship Dispatch fell in with many fields of this pumice-stone and wood, and was obliged to steer clear of them ; some of the pieces of wood were noted in its logbook as being about "six feet in diameter, and of very great length."

Trees of great size (many from sixty to eighty feet long) were thrown into the sea, some of which I saw in the bay of Beema; they seemed to have been scorched, and to have had their small branches and roots torn off. Some of those trees I saw sticking in the mud near the shores of the bay, with one end uppermost.

Some of the houses of the town of Beema were materially injured by the eruption; and I understand from our resident there, Mr. Pitott, that this had been occasioned by the discharges from the mountain.

In the bay of Beema the nature of the bottom was for some little depth changed from a soft mud to a firm mud, resembling a greyish-1)lack clay, which did not allow our ship's lead to sink in it. This change, I presume, was occasioned by the depth of Vol. 56. No. 265. Aug. 1820. 
volcanic dust which fell in the bay of Beema; for on mixing any quantity of the same dust with water, it soon sank to the bottom of the vessel containing the water, and formed there a firm substance, much the same in colour and consistence as the claylike matter which our lead and anchor brought up from the bottom of the bay of Beema. It is necessary, however, to mention, that although our lead could not penetrate through the layers of clay-like matter then on the bottom of the bay of Beema, our anchor did, and, on being heaved up when we left Beema, showed us both the sof mud which we had before the great eruption found all over the bay, and above that the lavers of firm mud which seem to have been made by the falling dust.

It was reported by Captain Eatwell, of the Honourable Company's cruizer Benares, that the earthquake attending the eruption had raised a bank on which that ship struck, in a place where the Honourable Company's cruizer Ternate some months before it had floated in safety.

The people living on the peninsula formed by the mountain had traded much in horses, of which their country produced a very good small breed. Thousands of them and their horses were, according to all accounts, destroyed by the eruption : the vegetation was ruined, and multitudes of the people obliged to enigrate in order to obtain subsistence.

I understand that at the town of Tanbora, situated at the bottom of the west side of the mountain, the sea has made a permanent encroachment, burying that town to the depth of three fathoms.

Three distinet streans of a dark-coloured lava, according to the report of the people on the island, issued from the hill ; of these I could observe something as I passed going to Beema in July following. One stream on the east side of Tanbora seemed to be emitting smoke and vapour even at that time.

During the darkness the sounds before described were particularly loud and frequent. At times, indeed, they were so loud at to produce momentary earthquakes of no inconsiderable violence.

All this while there was no wind in any direction in the neighbourhood of the mountain, or at some distance from it; yet the sea was so violently agitated as to wash away some houses near it on Sumbawa, and to throw on the beach near the town of Beema several large trading boats that had been at anchor in the bay.

One of the most remarkable circumstances of the eruption is the experience of its effects at immense distances. At Samanap, on the island of Madura, in lat. $70^{\circ} 5^{\prime} \mathrm{S}$. and in long. $113^{\circ} 57^{\prime} \mathrm{E}$., there wae, according to the information I received from Mr. Liddel, master attendant there, and who was at Samanap at the time, 
time, total darkness, in consequence of the falling lust, from 5 P.M. of the 11th of April until 11 A.M. of the 12th. The explosions were very loud at that place, and were heard for several davs.

At Somabaya the darkness was complete from about 6 P.M. on the 11 th until 4 P.M.on the 12 th. The sounds were described to me as beiug exceedingly loud. They had been heard at Samabaya, and dust had been observed to fall for several days before the 11 th, during which titne the wind was eastwardly and light: on the aftemon of the 11 th a very thick haze resembling a cloud was observed coning from the eastward. It proved to be the clond of dust from Mount Tanbora. The anchorage in Somahaya roads is in lat. $7^{\circ} 14^{\prime} \mathrm{S}$ and in long. $112^{\circ} 58^{\prime} \mathrm{E}$., i. e. about five degrees distant from 'Tanbora.

Similar but slighter effects of the eruption were felt at Batavia in lat. $6^{\circ} 10^{\prime} \mathrm{S}$. and in long. $106^{\circ} 5 \mathrm{l}^{\circ} \mathrm{E}$. ; at Java Head, still further off, being in lat. $6^{\circ} 4 \mathrm{~S}^{\prime} \mathrm{S}$. and in long. $105^{\circ} \mathrm{UJ}^{\prime} \mathrm{E}$.; at Minto, on the island of Barca, in lat. and in long. ; and at Bencoolen, or Sumatra, in lat. $3^{\circ} 48^{\prime} \mathrm{S}$. and in long. $102^{\circ}$ $28^{\prime}$ E.

At Macassar, in lat. $5^{\circ} 10^{\prime} \mathrm{S}$. and in long. $119^{\circ} 33^{\prime} \mathrm{E}$. the effects of the eruption were felt nearly at the same time as at Somabaya, but in a degree more violent.

The explosions from the volcano were so violent there, as to astonish every one; they shook the earth, and broke panes of glass in the windows of several houses. The cloud of dust was seen coming from the south. There was no wind.

With a view to ascertain the quantity of dust falling in a certain time, Mr. Paterson, surgeon of the residency there, put a table into the open air for an hour, between 6 and 7 P.M., at which time the dust was falling in great quantity, and the darkness total. The dimensions of the surface of the tahle were five feet two inches by four feet eight inches; the quantity of dust which fell upon it by 7 P.M. was 15,064 grains at Beeina; the quantity of dust found lying on the ground after the eruption was guessed to be at a medium of three inches and a half in depth: at Somabava the depth of it was something less.

At the island of Ternate, in lat. $0^{\prime} 49^{\prime} \mathrm{N}$. and in long. $127^{\circ}$ $29^{\prime} \mathrm{E}$., the explosions were distinctly heard about noou on the Ilth of April; dust was not perceived to fall there, nor did any person notice that that day, or any one of those immediately following, was at all darker than ordinary.

On the Island of Amboyna, on the 11 th or 12 th day of April in the same year, a violent earthquake was felt. In the ground of a gentleman near the Government-house, the earth was observed to open, to throw out a gush of water, and immediately 
after to close. The sea in the neighbourhood of Amboyna was violently agitated during that month, rising to high-water mark and sinking to low-water mark in the civurse of ten minutes. For several days, at the same time, the sun appeared (according to a letter from the late Lieutenant White, of the Bombay ma. rine, then at Amboyna) of a green colour, encircled with a haze. Fort Victoria, on Amboyna, lies in lat. $3^{\circ} 40^{\prime} \mathrm{S}$. and in long. $128^{\circ} 14^{\prime} \mathrm{E}$.

The inhabitants of the island of Banda, one of the Moluccas, experienced shocks of an earthquake at the time of the eruption of Mount Tanbora.

N. B. Some of the facts here mentioned are from my own personal knowledge, some from the information of individuals and from written documents on which I can rely; and some of them, more especially those concerning Sumatra, Banca, Amboyna, and Banda, are taken from the Java Government Gazette.

XV. Observations on the Phanomena of the Universe. By A Newtonian.

To Mr. Tilloch.

Sir, $-\mathrm{H}_{\text {AVING lately perused the Essays on the proximate }}$ mechanical Causes of the general Phænomena of the Universe, by Sir Richard Phillips, in which he endeavours to eclipse the immortal memory of the illustrious Newrov, $J$ have been induced to offer a few remarks respecting the theory of Sir Richard, which, like many other systems lately published, has, in my opinion, little or no foundation to support it.

Previously to offering any remarks, I shall make a few extracts from the above Essays:

1. Whatever be the origin of its own motion, the sun acts in the oeconomy of the planetary bodies, of the solar system, like the heart in the ceconomy of the animal system. Its own motion may be created by some arrangement within itself-by a perpetual motion of unknown contrivance, by the cross and reciprocal actions of the planets. The continued impulse of the sun on the mediun of space, or solar atmosphere, or both, must necessarily communicate to the entire sphere of its infuence a simultaneous rotation like the atmosphere of the earth. The orbicular motions of the planets will in that case be governed by a ratio of their distance, compounded with their densities, p. 65 .

2. Sir Richard inclines to think from reasoning a priori that every fixed star as a sin puts in revolution its own gaseous sphere, and by a revolving and diverging agency governs the general motions of the planetary bodies placed within its system or sphere of action, impulse, or rotation, p. 59. 